\title{
光合成速度，エチレン生成量からみた踏圧強度と 芝生の生育との関係について
}

\section{近藤 三 雄 ${ }^{*}$}

Growth of Lawn When Studied with Regard to Photosynthetic Rate and Formation of Ethylene-Effect of Treading.

Mitsuo KONDO

\begin{abstract}
摘要：本研究では芝生地の収容力を究明する一環として, 踏圧強度と芝生の生青との関係を生理的レベルで検証す ることを意闵した。その結果, 毎日 15 回連続 30 日間, 踏圧を加之た芝生の荠葉は草丈, 葉長の生育が著しく抑制 されるなど損耗し，光合成速度も無踏压の芝生に比べて半減することなどが判明した。なお，草丈，葉長などが著 しく抑制されるのは芝生に踏圧が加わることによって生成されるエチレンの作用によるものであることが判明し た。
\end{abstract}

\section{緒言}

本研究においては，芝生地の収容力を解明する研究の 一環として。踏圧の有無・強度の違いが芝生の生育に及 ぼす影響を生理的レベルで究明するてとを意図した。本 研究に関する従前の研究は. 踏圧強度と芝生の損傷度合. あるいは生育量などに注目したものばかりであり、芝生 面に過度の踏圧が加わることによって芝生の生理的機能 は.いかなる状態となるのかなどの点について究明した 研究事例は皆無である。また. 芝生に踏圧が加わること によって草丈、葉長が著しく抑制されるという現象は, 経験的によく知られていることであるが, 踏圧が加わる ことによって何故, 草丈, 葉長の生育が抑制されるかな どの因果関係については全く明らかにされていない。乙 のような背景から本研究においては，植物の生命維持や 生育を支える最も重要な機能といえる光合成能が過度の 踏圧を受けることによって，いかなる状態となるのかを 実証すること，また，国内外の農学の諸分野で明らかと なりつつある「踏む，触れるなどの接触刺激（物理的ス トレス）を植物に加えることによって茎葉から植物ホル モンの一種であるエチレンが生成され，乙のエチレンの 作用によって植物の地上部の生育が著しく抑制される」 という指摘 ${ }^{12) 324)}$ を基に, 芝生に加わる踏圧強度の違い による芝生の生育反応をエチレン生成量との関係から究 明することを意図した。さらに，乙れらの成果を基に芝 生地の利用の限界点, すなわち収容力について言及する ことを目論んだ。

\section{実験方法}

1.踏圧の有無が芝生の生育ならびに光合成速度に及ぼ す影響について

本実験においては. 過度の踏圧によって芝生が損耗し た場合，光合成速度が，いかなる状態となるかを検証す るととを目的に以下の方法で実験を行った。

\section{(1)実験材料ならびに実験区の設定}

東京都世田谷区にある東京農業大学の実験圃場に育成 しているコウライシバ (Zoysia matrella Merr.)の夕 ーフ（turf）を昭和59年6月 9 日に内径 $10 \mathrm{~cm}$ のホールカ ッターで採取し, 腐植性火山灰土（黒土）を充填した内 径 $11.3 \mathrm{~cm}$, 樑さ $6.3 \mathrm{~cm}$ の / 10.000 a NEUBAUER'S POTに植込み，8月10日まで約60日間養生したあのを実 験用芝生とした。なお。1 / 10.000.aの大きさの実験ポッ トに植込んだのは, 光合成速度测定上の便宜によるもので ある。

実験区については，過度な踏圧が加わった場合，芝生 の光合成速度が、いかなる状態になるのかを把握するた めに，養生しておいた実験用芝生を用い，体重 $63 \mathrm{~kg}$ の人 間が 8 月11日から連続して30日間，麦踏みの要領で 1 日 当り15回の踏圧を加えた実験区：30日間踏圧区（芝生面 にかかる接地圧に換算すると人間の運動時の平均接地压 $0.4 \mathrm{~kg} / \mathrm{cm}^{2} \times 15$ 回 $\times 30$ 日，累計 $180 \mathrm{~kg} / \mathrm{cm}^{2}$ 区）と，軽度な 踏圧が加わった場合の芝生の光合成速度が、いかなる状 態になるのかを把握するために，9月12日の1日のみ体 重63kgの人間が15回の踏圧を加えた区：1 日踏圧区（接 地圧に換算すると $6 \mathrm{~kg} / \mathrm{cm}$ 区）の 2 区を設定した。乙れ らの区と実験期間中，全く踏圧を加えずに放置しておい 
た区 : 無踏圧区（対照区）との光合成速度の比較測定を 行った。なお，15回/日（30日間踏圧区）の踏圧回数は, 明らかに芝生が損耗状態を呈することをねらい, 既往の 研究成果 ${ }^{6)}$ を基に設定したあのである。また，いずれの 実験区ともに実験用芝生は 5 ポットずつ用意したが, 光 合成速度等の測定には, その中で最も標準的な生育を示 した 1 ポットのみをあてた。

\section{(2)光合成速度の測定}

測定にあたっては, 写一1に示すような通気法・開放 系の装置で, 1/10.000 aNEUBAUER'S POT 亿植込 んだ実験用芝生の地上部に外気を通気 $(2.5 \sim 5 \ell / \mathrm{min})$

し. 温度 $25^{\circ} \mathrm{C}$ の $に 47 \mathrm{kl} x$ 前後の光の強さに対応する $\mathrm{CO}_{2}$ 交換量を赤外線ガス分析器を用いて測定し, 得られた結 果を所定の公式にあてはめ, 光合成速度を求めた。光合 成速度は, 1 時間に $100 \mathrm{~cm}^{2}$ ( $1 \mathrm{dm}$ ） の面積の葉がとり込 んだ $\mathrm{CO}_{2}$ のg数, すなわち $\mathrm{mgCO}_{2} / \mathrm{dm}^{2} / \mathrm{hr}$ で表示するて ととした。

なお，30日間踏圧区と無踏圧区との光合成速度の比較 測定は 9 月 10 日の午後 4 時から翌日の午後 5 時までの 25 時間, 1 日踏圧区と無踏圧区との比較測定は 9 月 12 日の 午前10時から翌日の午前10時までの 24 時間行った。また。 光合成速度を測定した実験用芝生については，測定後。 堀上げ調查を行い, 葉長, 葉幅、葉数、葉面積, 葉部・ 根部の生体重・乾物重などあ併せて計測した。

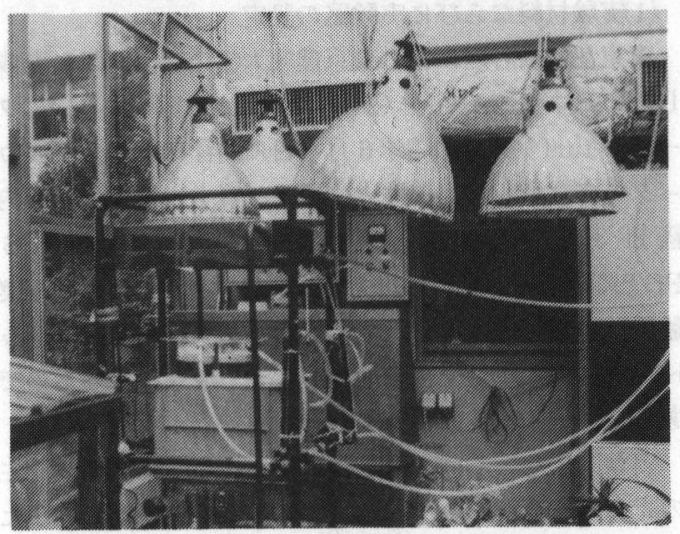

写-1 光合成速度測定風景

2.踏庄強度の違いによる芝生の生育反応とエチレン生 成量との関係について

本実験に扔いては, 芝生に様々な程度に踏圧を加えた 場合の生育反応とエチレンの生成量との関係を検証する ことを目的として。 以下に示すような内容で実験を行っ た。ただし, 今回は踏圧強度ならびにエチレン生成量が 根部の生育に及ぼす影響については言及しなかった。

(1)実験材料ならびに実験区の設定

東京都世田谷区にある東京農業大学の実験围場に育成 しているコウライシバ (Zoysia matrella Merr.) の
ターフを 7 区画（1区画： $52 \times 51 \mathrm{~cm})$ に区切り, 実験用芝 生とした。

実験区については, 1 日当りの踏圧回数を既往の知見 を基に, 踏圧による明らかな生育差がでることをねらい として, 無踏圧区 (対照区)，3回/日踏圧区，5回/日踏 圧区, 7 回/日踏圧区, 10回/日踏圧区, 15回 / 日踏圧 区, 20 回 / 日踏圧区の 7 段階に設定し, 体重 $63 \mathrm{~kg}$ の人間 が昭和59年 8 月21日から 9 月20日までの30日間連続して, 麦踏みの要領で踏圧を加えた。なお，1 1 月間, 所定の 回数の踏圧を加えた場合の芝生面にかかる接地圧を累計 して求めると 3 回 / 日区では $36 \mathrm{~kg} / \mathrm{cm}$ (人間の運動時の 平均接地圧 $0.4 \mathrm{~kg} / \mathrm{cm}^{2} \times 3$ 回 $\times 30$ 日), 5 回区では $60 \mathrm{~kg} /$ cmin, 7 回区では84kg/ cmin, 10回区では $120 \mathrm{~kg} / \mathrm{cm}, 15$ 回

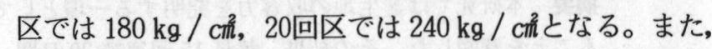
参考のため， 7 段階に設定した踏圧回数の30日分を累計 して, すなわち90 (3 回×30日), 150 ( 5 回 $\times 30$ 日), 210 ( 7 回 $\times 30$ 日), $300(10 \times 30$ 日), 450 (15回 $\times 30$ 日), 600 (20回 $\times 30$ 日) 回の踏圧を一度に連続してかけ, 各踏 圧強度とエチレンの生成量との関係をみるための実験む 併せて行った。

(2)エチレンの測定

エチレンの測定は 5 日抢きに行い, 測定にあたっては, 測定日の前日の午後 0 時前後（踏圧をかける前）に各 実験区ごとに 2 ～ 3 葉の着生した直立茎を 10 本ずつ採取 し, あらかじめ $1 m l の$ 蒸留水を入れておいた $32 m l の$ 試験 管に入れて密封し, $30^{\circ} \mathrm{C}$ 暗黒条件下で 20 時間以上, 1 ンキュベーションした後, ガスフロマトグラフィーによ って定量し, 1 時間当りに $1 \mathrm{~g}$ の葉が生成するエチレン の量を求めた。なお, 各実験区の芝生の生育状態を把握

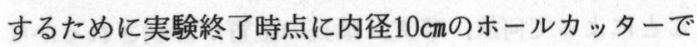
各実験区の夕ーフを採取し, 草丈, 葉長, 葉幅, 葉数, 葉面積, 葉部の生体重・乾物量などの計測を行った。

\section{実験結果ならびに考察}

1.踏圧の有無が芝生の生育ならびに光合成速度に及核 す影響について

実験結果については, 表一 1 , 図-1・2, 写一 2 亿 示す通りである。まず30日間踏圧区と無踏圧区との比較 測定結果から先に述べると, 30日間踏圧区では, 踏圧開 始後, 10 日目前後から地上部の損耗状態が判然とし始め, 実験終了時点では地上部はむとより写一 2 であ明らかな 通り, 地下部の生育も無踏圧区に比べて, はるかに劣る 状態となっている。このてとを裏付けるように, 堀上げ 調査をした結果に扔いても30日間踏圧区は無踏圧区に比 べて, 葉部の乾物重で $51 \%$ 減, 根部の乾物重で $27 \%$ 減, 葉数で $37 \%$ 減, 個体全体の葉面積で $38 \%$ 減, 葉長で $22 \%$ 減と明らかに生育量が低下しているととが判明した。光 合成速度の測定結果については図一1亿示す通りであり 
表一1 踏圧の有無がコウライシバの生育ならびに光合成速度に及ぼす影響について

（光合成速度の測定日：1984年 9 月 10 日〜11日）

\begin{tabular}{|c|c|c|c|c|c|c|c|c|}
\hline \multirow{2}{*}{ 実 } & \multirow{2}{*}{$\begin{array}{l}\text { 葉 長* } \\
(\mathrm{cm})\end{array}$} & \multirow{2}{*}{$\begin{array}{l}\text { 葉数 } \\
(\text { (枚) }\end{array}$} & \multicolumn{2}{|c|}{ 葉面積 $* *\left(\mathrm{~cm}^{2}\right)$} & \multicolumn{2}{|c|}{ 乾物 重 (g) } & \multicolumn{2}{|c|}{ 光合成速度 $\left(m g \mathrm{CO} 2 / \mathrm{dm}^{2} / \mathrm{hr}\right.$ ) } \\
\hline & & & 個体全体 & 1枚当り & 葉 部 & 根 部 & 最小値～最大值 & 平均値 \\
\hline 圧 区 & $\begin{array}{c}2.68 \\
(1.00)\end{array}$ & $\begin{array}{l}1248 \\
(1.00)\end{array}$ & $\begin{array}{l}126.8 \\
(1.00)\end{array}$ & $\begin{array}{l}0.1016 \\
(1.00)\end{array}$ & $\begin{array}{l}1.351 \\
(1.00)\end{array}$ & $\begin{array}{l}2.588 \\
(1.00)\end{array}$ & $12.35 \sim 20.01$ & $\begin{array}{l}14.96 \\
(1.00)\end{array}$ \\
\hline $\begin{array}{l}\text { 15回/日 } 30 \text { 日間 } \\
\text { 踏 王 区 }\end{array}$ & $\begin{array}{c}2.10 \\
(0.78)\end{array}$ & $\begin{array}{c}788 \\
(0.63)\end{array}$ & $\begin{array}{c}78.5 \\
(0.62)\end{array}$ & $\begin{array}{c}0.0996 \\
(0.98)\end{array}$ & $\begin{array}{l}0.659 \\
(0.49)\end{array}$ & $\begin{array}{l}1.885 \\
(0.73)\end{array}$ & $3.95 \sim 11.00$ & $\begin{array}{l}6.13 \\
(0.41)\end{array}$ \\
\hline
\end{tabular}

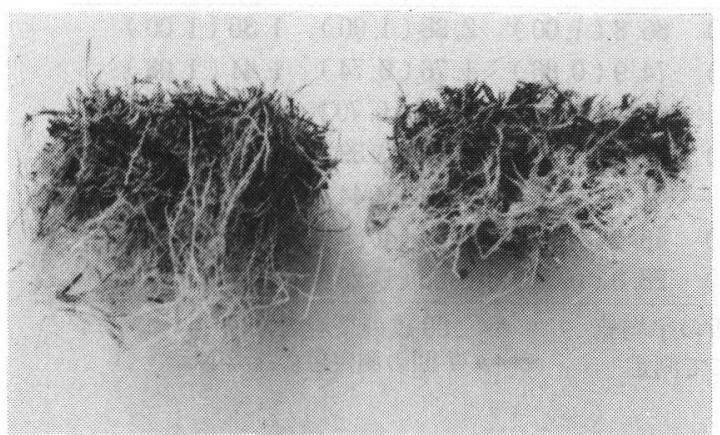

写一2 光合成速度測定個体堀上げ結果

左側：無踏圧区 右側：15回/日・30日間踏圧区

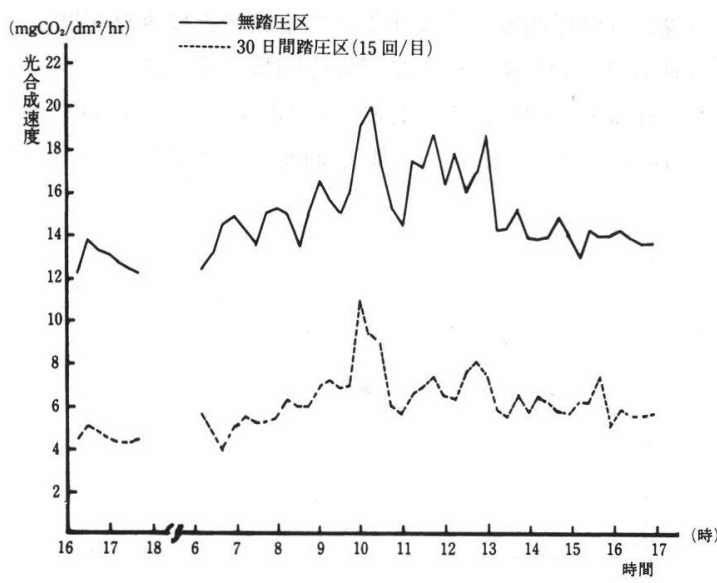

図一1＼cjkstart踏圧の有無によるコウライシバの光合成速度の 経時的変化(無踏圧区と30日間踏圧区との比較) （1984 年 9 月10日〜11日）

測定は 9 月 10 日の午後 4 時過より開始したが, 測定開始 時点から30日間踏圧区は無踏圧区に比べて, 光合成速度 は顕著に低く，その割合は測定時間中，常に一定であっ た。因みに30日間踏圧区の測定時間中の光合成速度の最 低値は $3.95 \mathrm{mgCO} 2 / \mathrm{dm}^{2} / \mathrm{hr}$, 最高値 $11.00 \mathrm{mgCO} / \mathrm{dm}^{2} / \mathrm{hr}$, 平 均値 $6.13 \mathrm{mgCO} / \mathrm{dm} / \mathrm{hr}$, (標準偏差 1.3337 ) と無踏圧区の 最低値 $12.35 \mathrm{mgCO} / \mathrm{dm}^{2} / \mathrm{hr}$, 最高値 $20.01 \mathrm{mgCO} / \mathrm{dm}^{2} / \mathrm{hr}$, 平均值 $14.96 \mathrm{mgCO} / \mathrm{dm}^{2} / \mathrm{hr}$, (標準偏差 1.844 ) 之30日間踏 圧区の光合成速度は無踏圧区の概小 1 / 2 以下であった。 一方， 9 月 12 日に 1 日のみ 15 回の踏圧を加えた 1 日踏
圧区の茎葉は,やや倒伏した状態となったが，外見的に は何らの損耗状態む観察されず，踏圧後間むなく，すな わち午前 9 時過に踏圧を加え, 午前10時加ら測定開始し た光合成速度は図一2に示すように，測定開始後間もな くは無踏圧区に比べて 1 / 2 以下と著しく少なかったが, 時間の経過とともに無踏圧区との差は徐々に小さくなり, 約 2 時間後には無踏圧区との差はなくなり，その後は測 定終了時点まで 1 日踏圧区と無踏圧区との光合成速度の 測定値には全く有意な差（ 5 \%水準）は認められなかっ た。

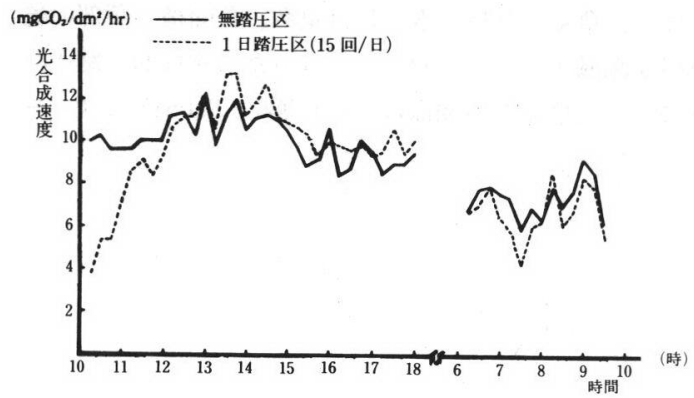

図一2 踏圧の有無によるコウライシバの光合成速度の 経時的変化(無踏圧区と 1 日踏圧区との比較)

（1984 年 9 月12日～13日）

以上, 15回 / 日の踏圧が連続30日間（接地圧でいえば $180 \mathrm{~kg} / \mathrm{cm}$ ））加わると, 無踏圧区に比べてコウライシバ の生育量, 光合成速度は顕著に低下し, コウライシバの 生育にとって重大な影響を及ぼすが，15回の踏圧が 1 日 だけ（接地圧でいえば $6 \mathrm{~kg} / \mathrm{cm}$ ）加わった程度では, 外 見的にも何の影響も観察されず，また，光合成速度屯踏 圧直後に一時的に低下するが, 間もなく無踏圧区之同様 な程度に回復するなど, コウライシバの生育を阻害する ような影響は全く認められなかった。

2.踏圧強度の違いによる芝生の生育反応とエチレン生 成量との関係について

実験結果については, 表一 2 , 図一 $3 ， 4 ， 5$ 亿示す 通りである。まず所定の踏圧回数を連続して 30 日間加え た実験の踏圧強度の違いによるコウライシバの生育反応 との関係についていえば, 踏圧開始後10日目を過ぎる頃 から踏圧を加えた各区の草丈, 葉長の生育が無踏圧区に 比べて抑制され始め，10回/日踏圧区，15回/日踏圧区, 
20回 / 日踏圧区の各区においては, 地上部の損耗も徐々 に明らかとなり，実験終了時点では15回 / 日踏圧区，20 回 / 日踏圧区では一部分で裸地化現象む認められるなど, 損耗状態が著しかった。各実験区のターフを堀上げ調査 をした結果は表一 2 に一覧してあるが, 踏圧強度の増加
に比べて, 15回 / 日踏圧区では草丈が54\%減, 葉長が26 \%減, 葉数が $45 \%$ 減, 堀上げ個体全体の葉面積が $46 \%$ 減, 葉部の乾物重が $62 \%$ 減と生育量が50\%内外減じ, 20 回 / 日踏圧区では草丈が $60 \%$ 減, 葉長が30\%減, 葉数が $61 \%$ 減, 墰上げ個体全体の葉面積が $68 \%$ 減, 葉部の乾物重が

表一2 踏圧強度の違いによるコウライシバの生育とエチレン生成量との関係について

\begin{tabular}{|c|c|c|c|c|c|c|}
\hline 実 験 区 & 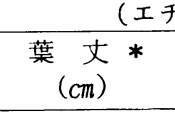 & $\begin{array}{l}\text { 葉 長 } * * \\
(\mathrm{~cm})\end{array}$ & 葉数（枚） & $\begin{array}{l}\text { 個体全体 *** } \\
\text { の葉面積 }\left(\mathrm{cm}^{2}\right)\end{array}$ & $\begin{array}{l}\text { 葉 部 } \\
\text { 乾物重 }(g)\end{array}$ & $\begin{array}{l}\text { エチレン生成量 ***** } \\
(\mathrm{nl} / \mathrm{g} \mathrm{FW} / \mathrm{hr})\end{array}$ \\
\hline 無 踏 圧 区 & $2.37(1.00)$ & $2.37(1.00)$ & $815(1.00)$ & $86.8(1.00)$ & $2.38(1.00)$ & $1.30(1.00)$ \\
\hline 3 回 / 日踏玕区 & $1.69(0.71)$ & $2.06(0.87)$ & $619(0.76)$ & $74.9(0.86)$ & $1.76(0.74)$ & $1.41(1.08)$ \\
\hline 5 回 / 日踏圧区 & $1.53(0.56)$ & $2.03(0.86)$ & $643(0.79)$ & $67.8(0.78)$ & $1.67(0.70)$ & $1.64(1.26)$ \\
\hline 7 回 / 日踏圧区 & $1.55(0.57)$ & $1.76(0.74)$ & $478(0.59)$ & $44.5(0.51)$ & $0.94(0.39)$ & $1.69(1.30)$ \\
\hline 10回 / 日踏王区 & $1.31(0.48)$ & $1.71(0.72)$ & $499(0.61)$ & $41.7(0.48)$ & $1.04(0.44)$ & $1.47(1.13)$ \\
\hline 15回 / 日踏圧区 & $1.25(0.46)$ & $1.76(0.74)$ & $451(0.55)$ & $46.6(0.54)$ & $0.90(0.38)$ & $1.76(1.35)$ \\
\hline 20[回 / 日踏圧区 & $1.10(0.40)$ & $1.67(0.70)$ & $321(0.39)$ & $28.0(0.32)$ & $0.68(0.28)$ & $1.83(1.41)$ \\
\hline
\end{tabular}

注）（）内の数值は無踏圧区に対する比率＊10筒所の平均值 ***個体から全ての葉を切りはずし自動面積計にて測定

**** 7 回の測定值の平均値

に伴い, 草丈, 葉長, さらには葉数, 葉面積, 葉部の乾 物量が漸減するととが明らかとなった。すなわち踏圧回 数の違いと草丈との関係は $\mathrm{Y}=1.985-0.0515 \mathrm{X}(\mathrm{r}=-$

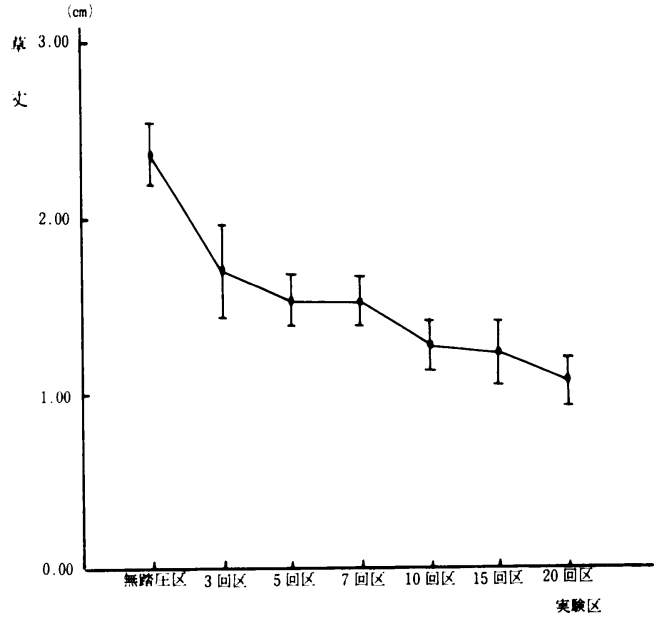

図一 3 コウライシバ芝生における踏圧強度と草丈との関 係(平均値のグラフ)(調査日：1984年 9 月21日) $0.8660)$, 踏圧回数の違いと葉長との関係は $\mathrm{Y}=2.171$ $-0.0305 X(r=-0.8364)$, 踏圧回数の違いと葉数との関 係は $\mathrm{Y}=727.5428-21.1133 \mathrm{X}(\mathrm{r}=-0.9233)$, 踏圧回数 の違いと堀上げ個体全体の葉面積との関係は $\mathrm{Y}=78.8564$ $-2.6982 X(r=-0.8997)$, 踏圧回数の違いと葉部乾物重之 の関係は $\mathrm{Y}=0.6410-0.0254 \mathrm{X}(\mathrm{r}=-0.8812)$ という 回㷌式で示されるような関係があり, いずれあ有意（1 \%ないし $5 \%$ 水準) な負の相関関係があることが認めら れた。殊に一部に裸地化現象が認められた15回/日踏圧 区, 20回 / 日踏圧区で生育量の低下が顕著で, 無踏压区
$72 \%$ 減と大略60\%以上生育量が減じたとみなせる。

5 日おきに測定した各実験区のエチレンの生成量につ いては表一 2 , 図- 4 - 5 亿示す通りであり, 踏圧回数 の違い（踏圧強度）とエチレンの生成量とは大略相関し, 各測定日の平均値でいえば, 踏圧回数の違いとエチレン の生成量との関係は $\mathrm{Y}=1.387+0.023 \mathrm{X}(\mathrm{r}=0.830)$ と いう回帰式で示され (図-4), 有意 ( $5 \%$ 水準) な正の

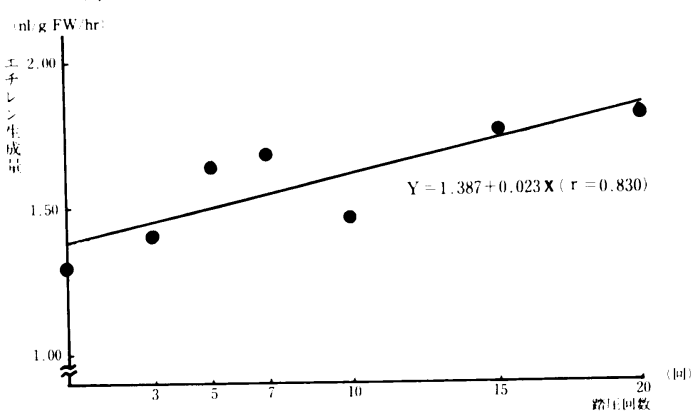

図一4 コゥライシバ芝生における踏圧強度の䢖いとエ チレン生成量との関係(測定日：1984 年 8 月22 日〜9月21日)

相関関係のあることが認められた。すなわち踏圧回数の 増加に伴いエチレンの生成量が漸増する関係が明らかと なった。ただし10回 / 日踏圧区のエチレンの生成量の平 均值が $3 \cdot 5 \cdot 7$ 回/区に比して低かったのは, 踏压の 加えられた部分の茎葉の採取が均一にできなかったなど の測定資料のサンプリング上の問題から生じた結果と推 察される。なお，15回 / 日踏圧区, 20回 / 日踏圧区と無 踏圧区とでは, 図一 5 亿一部示すように, 各测定日のエ チレンの生成量に有意 ( 5 \%水準) な差が認められたて とは, 踏圧という接触刺激 (物理的ストレス) によって 


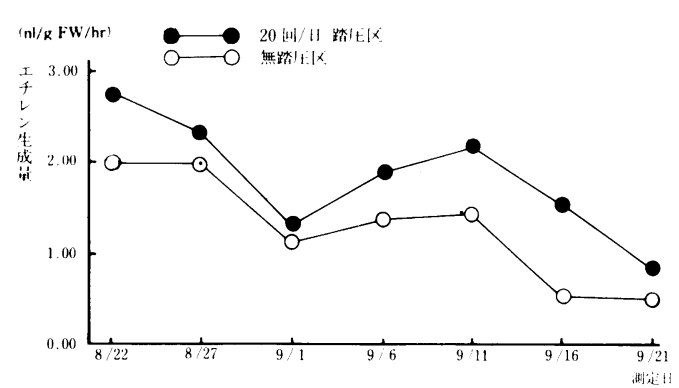

図一5 コゥライシバ芝生における無踏圧区と踏圧区 (20回/日) とのエチレン生成量の比較 (1984 年)

コウライシバの茥葉からのエチレン生成量は明らかに高 まるという事実を確証するあのである。また，既知の事 実であるが, 気温の低下に伴い, エチレンの生成量が漸 減することも本実験の結果からも伺われた。

なお, 各実験区のエチレン生成量と草丈との関係はY $=4.2648-1.7165 X(r=-0.8060)$, エチレン生成量と 葉長との関係は $\mathrm{Y}=3.4858-0.9946 \mathrm{X}(\mathrm{r}=-0.7624)$ という回帰式で示され，有意（5\%水準）な正の相関関 係があることが認められた。すなわちエチレンの生成量 が高まると草丈，葉長の伸長が㧕制されるという関係が 明らかとなった。前述した踏圧回数とエチレンの生成量 とは正の相関関係があるということと考えあわせると踏 圧強度の增加に伴い, エチレンの生成量が高まり, その 結果, 草丈, 葉長の伸長が抑制されるという划式が成り 立ち, 太田らの「んギ踏みは体重をかけて踏みつけるの で，相当に大きな物理的な刺激を人ギに与えることにな る。その刺激に反応してィギはエチレン生成量を増大し， 草丈の伸長が抑制される」7) と指摘される既知の事実と完 全に合致する。換言すれば，本実験によって，「踏圧が加 わるととによって芝生の草丈の伸長が抑制される」とい う多くの人々が，乙れまでに認めていた現象は，実は踏 压という接触刺激によってェチレンが生成され, 生成さ れたエチレンが一つの抑制因子となって現われる現象で あるという因果関係が明らかになったといえる。

次に $3 \sim 20$ 回の所定の踏圧回数の30日分を累計して, すなわち90，150，210，300，450，600回の踏圧を 一度に連続して加えた場合のエチレンの生成量を 9 月 21日に測定した結果, 90回踏圧区で $1.25 \mathrm{nl} / \mathrm{g} \mathrm{FW} / \mathrm{hr}$ 150 回踏告区で $1.74 \mathrm{nl} / \mathrm{gFW} / \mathrm{hr}, 210$ 回踏圧区で1. 60 $\mathrm{nl} / \mathrm{gFW} / \mathrm{hr}, 300$ 回踏圧区で $2.35 \mathrm{nl} / \mathrm{gFW} / \mathrm{hr}, 450$ 回踏庄区で $2.83 \mathrm{nl} / \mathrm{gFW} / \mathrm{hr}, 600$ 回踏压区で $2.31 \mathrm{nl}$ / gFW/ hrであった。乙の結果は, 1 日当り 3 〜20回の 踏压を加えた場合に比べると, はるかにエチレンの生成 量は大であり, しかあ, 乙の場合の踏圧回数の違いと工 チレンの生成量との関係は $\mathrm{Y}=0.9847+0.0031 \mathrm{X}(\mathrm{r}=$ 0.8535 ) という回帰式で示され, 有意 ( $5 \%$ 水準)な正 の相関関係があるととが認められた。したがって, ての 結果からも踏压強度が増すととによってェチレンの生成
量が漸増する事実が確認された。なお，乙の実験の場合 の踏圧強度がコウライシバの地上部に及ぼす影響につい て観察した結果を述べると, 90〜600回踏圧区のいずれに おいても茥葉が倒伏した状態となり，300回踏圧区（10 回×30日), 450回踏圧区 (15回×30日),600回踏圧区 (20 回×30日）においては損耗が明らかとなり，しかも450回 踏圧区, 600 回踏圧区においては, 一部, 裸地化状態が 観察された。乙の結果と前述した実験結果と考え合わせ ると，3〜20回の踏圧を毎日30日間加えた場合と30日間 分を累計し，一度に連続して踏圧を加えた場合とでは, 芝生に与えるダメージは大差ないと判断される。

\section{結論}

本実験の結果, 15回/日の踏圧が30日間連続してコウラ イシバに加わると, 草丈, 葉長, 葉数, 葉面積など生育 量か顕著に減少するばかりでなく，無踏压の状態のもの に比べると光合成速度む $1 / 2$ 以下に減少するなど，生体 維持上，かなりのダメージを受けることが判明した。ま た, 芝生面にかかる踏圧強度の増加に伴い, 茎葉からの エチレンの生成量が高まるとと, さらには踏圧により草 丈, 葉長が著しく抑制されるのは, このエチレンの作用 によるあのであるてとが既往の知見と照合するてとによ って明らかとなった。このことは従前からいわれている 芝生面に踏圧あるいは転圧が加わると, 芝生の草丈が抑 制されるという経験的事実の因果関係をシバの生育生理 から説明したものといえる。

なお, 本実験の結果を基に芝生地の利用の限界点, す なわち収容力について言及すると, 公園等の芝生地にお いて, 芝生を完全に裸地化させないためには, 芝生地で の 1 ケ月間の利用者の踏圧強度を最大に見積っても累計 450 回/月（接地压でいえば $180 \mathrm{~kg} / \mathrm{cm}^{2}$ ）以下に抑える ことが要件となる。ただし, 今回の実験は完全なターフ を形成している芝牛で行ったものであり, ターフが十分 形成されていない造成後間もない芝生，あるいは $4 \sim 5$ 月の芽出しの時期の芝生に执いては, 芝生の耐踏圧性は, より劣ると考えられるため, 450 回/月よりも低い值が, 芝生を完全に裸地化させないための目安数値となるとい える。

また, 本実験で得られた結果から,さらに言えるてと として，ほとんど人の立入り利用をさせない観賞芝生, あるいはのり面等の芝生などにおいては, 適宜, 転压あ るいは踏圧, さらには他の方法で接触刺激（物理的スト レス）を与えることによって，エチレンの生成量を高め， 芝生の草丈を抑制し, 緻密な芝生に仕上げる, また, 刈 込の手間を省くなど実利的な効果をあげる目論みも期待 できる。

最後に, 本研究を実施するにあたり, 御指導・御助言 を頂いた東京農業大学造園地被・植栽学研究室, 小沢知 
雄教授ならびに東京農業大学作物学研究室, 田辺猛教授 玉井富士婎講師, 東京農業大学アイソトープ研究所, 太 田忠親講師に深甚の謝意を表する。

\section{引用ならびに参考文献}

（1)太田保夫（1974）：植物の接触形態形成とエチレン：

農業および園芸 49 ( 9 ), 21-25

(2)太田保夫（1975）：植物に対する接触刺激と生長抑制

: 植物の化学調節 $10(2), 90-94$

(3)太田保夫（1983）：接触刺激による作物の生育制御法

: 農業および園芸 58 ( 4)，9-14
(4)下川敬之（1979）：エチレンの生理・生化学14：農業 および園芸 54（6)，112-118

(5)二股正年他（1970）：自然草地の改良と牧養力の向上 に関する研究：北海道農業試験場報告 $77,126-130$ (6)近藤三雄他（1977）：芝生地の収容力に関する基礎的 研究 (I ) 一一踏圧一土㙵硬度に対する芝生地の植群の 低抗性からみた収容力について一：造園雑誌 40 (3), $11-23$

(7)太田保夫（1980）：植物の一生とエチレン：東海大学 出版会, 106

Summary : The purpose of this study is to verify the growth of lawn in relation to treading as part of an investigation conducted to discover the capacity of a stretch of turf on a physiological level. A number of findings were collected. What is noteworthy here is the results of an experiment in which pressure was applied to lawn by treading on it 15 times a day for a period of 30 days in succession; a control was prepared for comparisons. It was found that the growth of lawn, if treaded on, will be suppressed significantly; the growth of the stem and leaves in terms of their length was hindered, if not prevented all together. The photosynthetic rate, moreover, dropped to half that of the lawn used as the control. It was later found that the limited growth of the stem and leaves was due to the work of ethylene being formed by the pressure on the lawn. 